\title{
Article \\ Does Antwerp Belong to Everyone? Unveiling the Conditional Limits to Inclusive Urban Citizenship
}

\author{
Nicolas Van Puymbroeck ${ }^{1, *}$, Paul Blondeel ${ }^{2}$ and Robin Vandevoordt ${ }^{1}$ \\ ${ }^{1}$ Centre on Inequality, Poverty, Social Exclusion and the City, University of Antwerp, Sint-Jacobsstraat 2, 2000 Antwerp, \\ Belgium; E-Mail: nicolas.vanpuymbroeck@uantwerpen.be (N.V.P.), robin.vandevoordt@uantwerpen.be (R.V.) \\ ${ }^{2}$ Faculty of Design Sciences, University of Antwerp, Sint-Jacobsstraat 2, 2000 Antwerp, Belgium; \\ E-Mail: paul.blondeel@uantwerpen.be \\ * Corresponding author
}

Submitted: 15 February 2014 | In Revised Form: 23 May 2014 | Accepted: 27 May 2014 |

Published: 17 September 2014

\begin{abstract}
Recent theoretical discussions have indicated that citizenship is not only a way of being, but also a way of behaving. This article aims to show how attempts to regulate the behaviour of the citizenry can introduce a new topography of inclusion and exclusion, thereby exercising a direct effect on particular ethnic minorities. We investigate the issue in Antwerp, the largest city of the Flemish Region in Belgium. With his slogan 'Antwerp belongs to everyone' former mayor Patrick Janssens gained significant international attention for Antwerp's supposedly inclusive conception of urban citizenship. In this article, we argue that the universality of Antwerp's city slogan has nevertheless veiled the introduction of new exclusionary prescriptions centred around citizens' conduct. Drawing on a Foucauldian account of power, three different modes of policing are discussed that have rearticulated the boundaries of urban citizenship in Antwerp. The disciplinary, bio-political and etho-political techniques of power each show in a different way attempts by the state to steer and effectively regulate what counts as appropriate conduct. As a corollary of governmental power, particular ways of behaving have been labelled as deviant and abnormal, thus rendering full citizenship conditional on a set of substantial expectations on how to perform as a citizen. As these expectations are only apparently neutral with respect to ethnic identities, a tension arose between the city's universal and inclusive rhetoric and its particular and exclusionary policies.
\end{abstract}

\section{Keywords}

exclusion; Foucault; governmentality; Marshall; power; urban citizenship

\section{Issue}

This article is part of the special issue "Policing Ethnicity: Between the Rhetoric of Inclusion and the Practices and Policies of Exclusion", edited by Professor Abby Peterson (University of Gothenburg, Sweden) and Professor Malin Åkerström (University of Lund, Sweden).

(C) 2014 by the authors; licensee Cogitatio (Lisbon, Portugal). This article is licensed under a Creative Commons Attribution 4.0 International License (CC BY).

\section{Introduction}

In 2008 Patrick Janssens, the mayor of Antwerp, Flanders' largest city, was shortlisted for the World Mayor Award. His nomination represented a landslide change in the city's international reputation, which had deteriorated ever since it had become the hotbed for the
Flemish ultra-right-wing party Vlaams Blok in the 1990s and what has been labelled to be 'Muslim riots' in the early 2000s (De Decker, Kesteloot, De Maesschalk, \& Vranken, 2005; Swyngedouw, 2000). By 2003, the inability of authorities to regain control over the city came to a climax when the entire municipal government resigned after a corruption scandal involving some of its 
leading politicians. The socialist politician Patrick Janssens then entered the scene as the new mayor, announcing a different political future for the city. To counter the widespread image of a highly 'divided city', he immediately launched a new slogan which was to embody Antwerp's identity for years to come: 'The city belongs to everyone.'

The city slogan gained significant international attention for its supposedly inclusive conception of urban citizenship. Compared with the divisive political program of the extreme right it indeed explicitly distanced itself from any legal exclusion of unwanted persons. However, in this article we want to raise some critical questions about what it means for the city to belong to everyone. We argue that the universality of Antwerp's slogan has in fact veiled the introduction of a set of new exclusionary prescriptions that define what citizenship is and who belongs to the city. In our interpretation some policy measures expect the behaviour of citizens to correspond to the standard of the 'good citizen'. Yet this often also tends to exclude a range of individuals, often the most vulnerable categories in society like homeless people, immigrants, tenants, or poor people. Rather than being excluded legally, they risk being degraded to a form of second-class citizenship.

In the field of Urban Politics many authors have approached the issue of contemporary societal exclusion from the perspective of who factually runs the city (Smith \& McQuarrie, 2012). The general argument is that those who remain at the margins of the political power structure will be excluded from the city in various ways. Separate bodies of research have therefore looked into the distribution of power over gentrification (Smith, 1998), public space (Mitchell, 2005), homelessness (De Verteuil, 2006) and migrant policies (Uitermark, Rossi, \& Van Houtum, 2005) across many cities.

Even though the Urban Politics approach is valuable in its own right, it has overemphasized the question of who is responsible for exclusionary policies, at the expense of understanding how these policies factually exclude people. In addition, research somewhat lost sight of the broader connection between several exclusionary policies. Discussions on 'the right to the city' (Marcuse, 2009) or the 'just city' (Fainstein, 2010) have pointed in general to the exclusionary effects intrinsic to the contemporary capitalist city, yet they suffer from an analytical deficiency to account for the specific nature of different forms of exclusion.

This article will therefore draw on a Foucauldian reading of power techniques to complement the dominant perspective on who is responsible for exclusionary citizenship policies. Foucault $(1988 ; 2004)$ approaches power from a 'depersonalized' perspective whereby who is in power is not of foremost importance. His work is therefore well-suited to discuss how the governmental reach of the state tries to steer and effectively regulate the behaviour of its citizens. It is espe- cially useful to distinguish the underlying rationale and structure of power techniques that regulate who counts as a citizen and who doesn't.

We begin this article with a theoretical sketch of the distinction between a classic Marshallian approach to citizenship and a Foucauldian approach. Then we will discuss three different case studies that each illustrate a distinct power technique regulating the boundaries of urban citizenship. While the three illustrations only focus on the city of Antwerp, the theoretical leverage of the analysis is much broader. As scholars working in the field of Urban Politics have extensively shown, exclusionary policies are popping-up across the globe. This paper is a first attempt to classify the nature of these policies building on a Foucauldian take on power. To conclude, we will show how the different power techniques are interconnected and add up to a new urban topography of in- and exclusion.

\section{The Political Construction of Citizenship}

\subsection{The Renaissance of Citizenship: from Being to Behaving}

Sociological research on citizenship has long been inspired by T.H. Marshall's (1963[1998]) account of 'Citizenship and Social Class'. At the dawn of the era of the European welfare state, he argued that the relationship between citizens and the state had gone through a natural process of rights extension. Distinguishing between three periods, Marshall saw the rise of formalized citizenship in the $18^{\text {th }}$ century when the state became the protector of civil rights such as free speech, in exchange for complying with civil duties such as paying taxes. In the $19^{\text {th }}$ century, a second rights dimension was added: (some) citizens obtained political rights, enabling them to legitimately elect representatives. Finally, social rights were added to the bundle in the middle of the $20^{\text {th }}$ century, as the state obtained responsibility over the welfare of its citizens. Sociological research subsequently showed that the bundle of civil, social and political rights varied depending on the type of welfare state or political system.

In the late 1990s, research on citizenship experienced a sudden renaissance (Isin \& Turner, 2007), mainly due to the rise of the 'active' welfare state. The Marshallian approach seemed unable to understand how states could regulate the behaviour of their citizenry without modifying the bundle of rights. It became increasingly clear that Marshall had only grasped the juridico-political dimension of citizenship. For authors like Nikolas Rose (2000), Barry Hindess (2000), Mike Raco (2003), Engin Isin (2002) and Willem Schinkel (2010) however, citizenship was a more complex phenomenon.

These authors argued that citizenship is not only a legal status granted to individuals, but also entails a set 
of expectations on how to behave as a citizen. A central source of inspiration to understand this 'culturalized' dimension of citizenship was the work of Michel Foucault. As Olson (2008) summarizes, the Foucauldian approach to citizenship shares the "claim that citizenship is not simply a legal status conferring political rights and obligations, but one that additionally shapes identities and forms of subjectivity. Here citizenship not only certifies political membership, but more profoundly serves as a means of social differentiation and of fabricating interests, opinions, and preferences." (2008, p. 40).

The Foucauldian approach importantly shed new light on the principles of inclusion and exclusion from citizenship (Barry, Osborne, \& Rose, 1996). For Marshall and his followers the distinction between citizens and non-citizens was unambiguous and formalized: exclusion from the political community implied the subduction of membership status or the restriction of rights and duties. Foucauldian scholars saw citizenship as 'conditional' and 'virtual' (Schinkel, 2010). Apart from a juridico-legal sense of belonging, citizens are often asked to 'perform' certain expected behaviour as a condition to become a full citizen. Exclusion from the political community then occurs when formally recognized members do not comply with the required behaviour of the 'good citizen'.

This is the point where 'ethnicity' enters the picture. At least since Fredrik Barth's (1969) classical work, scholars have been at pains to emphasize the cultural nature of ethnicity. As Malešević (2004, p. 4) argued recently, ethnicity is now generally understood as "(...) a social relation in which social actors perceive themselves and are perceived by others as being culturally distinct collectivities". The logical consequence is that, in contemporary societies, ethnicity is policed primarily through cultural conceptions of citizenshipthat is, through policy measures enforcing norms of ideal behaviour, in the process shaping citizens' identities and subjectivities. In the cases discussed in this article (see Section 3) we will focus more particularly on how policy measures which appear to be ethnically neutral, nevertheless have direct consequences for very particular ethnic groups organized around modes of behaviour constitutive for their identities.

To understand how ethnicity is being policed today, we therefore need to focus on the instruments that governments have developed to steer citizens' conduct, their ways of life and the experience of their identities. According to Foucault, these advanced 'power techniques' are distinct from sovereign power instruments in the sense that they do not use physical force, such as incarceration or bodily violence. Instead of physically repressing its subjects, the power techniques that regulate the daily behaviour of citizens depend on the latter's cooperation to understand and comply with the requisite behaviour. Citizens are se- duced to identify with the state and its demands because these are portrayed as rational and in the best interest of the individual. Ultimately the exercise of these types of power tries to annul itself: citizens should internalize the requisite habitus as natural. Those who fail to comply, are not threatened with juridical exclusion from the community, but risk being stigmatized within the boundaries of the state. Their citizenship becomes second-rate because they do not comply with the hegemonic view on society.

The main advantage of such a Foucauldian approach is that it enables an in-depth analysis of the power techniques used to 'police' the cultural dimensions of citizenship, which are crucial to understand how ethnicities are policed today. On the other hand, this approach's main weakness is that some of the boundaries usually drawn between forms of exclusion are increasingly blurred. Most research on social exclusion is indeed differentiated with respect to the substantial 'identity' of its subjects (e.g. class, ethnicity, gender,...). In other words, while using a Foucauldian approach enables us to analyse the instruments with which ethnicity is being policed, it no longer allows us to distinguish sharply between the policing of ethnicity and, for instance, class and gender. In many cases, as we will demonstrate further below, these exclusionary techniques operate identically for different groups of subjects. In the following section, we will therefore shortly elaborate on three such power techniques.

\subsection{Three Power Techniques}

The regulation of citizens' conduct can take on a multiplicity of forms dispersed over many societal domains. Despite this variety, Foucault has tried to organize them into more generic types, in particular 'disciplinary power' and 'bio-politics' of the population (sometimes also referred to as the power of security).

Disciplinary power is composed of a set of techniques that are aimed at subjecting an individual to a particular code of conduct (Foucault, 2001). The use of this type of power is highly localized in specific institutions (e.g. clinics, prisons or schools). The internal structure of these institutions regulates the spontaneous behaviour of individual persons. In the context of the active welfare state, for instance, we think of the power exercised by public employment services. The unemployed are expected to register at regular intervals at the employment office to report on their activities of job-seeking. The take-up of their social rights is thereby made conditional on their collaboration with the employment service. Although repressive sanctions do exist, the ultimate goal of service providers is qualitatively different: they want to educate people and strengthen their labour skills. Compliance is mainly assured by convincing subjects that it is in their best interest to find a job. Employment agencies thus pro- 
mote the meritocratic ideal in which happiness and societal prestige derive from income and work. This productive power over subjects operates according to the principle of the norm. This means that it evaluates individual progression against a common standard. So if most people need three months to apply for a job, everyone should. As a result, people who do not fit the norm, for example because there is little demand for their specific expertise, are stigmatized as unwilling to work.

The second power type, bio-politics of the population, is less tied to specific institutions (Foucault, 1984). Instead, it aims to establish order in a community in its totality, that is, across institutional boundaries. Rather than regulating the conduct of individual persons according to a norm, this power type is exercised over citizens as a 'population'. It starts out from a specific view on what a 'normal' population should look like, and tries to identify the necessary parameters to change from the existing distribution of citizens to a normal one (Foucault, 2008). In our earlier example of the active welfare state measures to counter the 'unemployment trap' give a good illustration of bio-political control. Often the surplus income of work is very meagre for the low-skilled unemployed, dissuading them to look for a job. Many people consider this to be an abnormality in the social security system. Lowering benefits might be a parameter for the system to restore its balance. Again, this normalization can entail serious exclusionary consequences, for example in establishing the so-called 'working poor'.

Foucault's power typology is historical, which means that it remains principally open to new types of power. In this respect, authors have so far highlighted one additional type. Rose (2000, p. 1399) distinguished a new 'politics of behaviour' called 'etho-politics': "If discipline individualizes and normalizes and bio-power aggregates and socializes, etho-power works through the values, beliefs, and sentiments thought to underpin the techniques of responsible self-government and the manifestation of one's obligations." Etho-politics dig deeper into what Raco (2009) has called the "existential dimension' of citizenship. Just like disciplinary power it 'individualizes' a political subject, yet it does not operate in a special place or institution, and it can be exercised virtually anywhere and at any time. A good example is the possibility to take into account a broad range of private information, often distributed through social media, to evaluate people's claims on social benefits. The possibility of permanently controlling private conduct is used to encourage citizens to reflect on their public ethos, and to behave as the norms prescribe.

Important in this account of the power techniques is that they do not exclude one another: "So, there is not a series of successive elements, the appearance of the new causing the earlier one to disappear. There is not the legal age, the disciplinary age, and then the age of security. (...) In reality you have a series of complex edifices in which (...) what above all changes is the dominant characteristic, or more exactly, the system of correlation (...)" (Foucault, 2007, p. 8). This implies that repressive sovereign techniques often accompany techniques aimed at the regulation of behaviour. Nevertheless, the way in which these techniques link up and are discursively legitimated can take many forms. Foucault coined the neologism 'governmentality' or 'governmental rationality' to refer to the overall construction of power over citizens as individuals and as a population.

To sum up, we can say that our theoretical approach draws on the insight that citizenship implies more than a mere legal relationship, it also entails a cultural dimension. Inspired by Foucault, we distinguish different techniques of power that the state can employ to substantively regulate the conduct of its citizenry. As a correlate of this, different modes of conduct appear as abnormal and do not receive full recognition in society.

\section{Antwerp, a City that Belongs to Everyone?}

The remainder of this article will reconstruct in detail how Antwerp's municipal government developed its own conception of urban citizenship between 2003 and 2012 , a period in which the city was governed by a socialist-led coalition. We focus mainly on three sets of policy measures which gave rise to tense public debates because of their implications for particular groups of subjects, not in the least for ethnic minorities. First, we reconstruct the factual origins and official goals of each of the policy measures. For this purpose, we draw on in-depth interviews, public policy documents, Community Council minutes and statistics from municipal and regional authorities. Secondly, we propose to interpret the policy measures as illustrations of the three Foucauldian power techniques discussed above, i.e. the disciplinary, bio-political and ethopolitical power techniques. With the help of our theoretical framework, we try to enrich our understanding of these measures' general rationale and functioning of these policy measures, thus linking it with the city's emerging conception of citizenship. From this we derive whether and how new boundaries of exclusion arose. While it is not our aim to evaluate or criticize these policy measures, we do seek to lay bare these measures' exclusionary effects.

As a result, our interpretative reading shows clear affinities to Foucauldian Discourse Analysis (Mitchell, 2009), by focussing on the disarticulated practical effects of official policies and its legitimations. We do not contend our interpretation of the policy measures to be exhaustive, but the Foucauldian lens should offer a way to recast the rhetorical force of city marketing by critically asking what it means to live in a city that pre- 
sents itself as 'inclusive'.

\subsection{Disciplinary Power and the Neutrality of Service Provision}

On March 7, 2007 Antwerp's municipality introduced a dress code for city staff, which became better known as the 'headscarf ban in public functions'. Nonetheless, in its original formulation the guideline did not mention any garments in particular. It merely defended a general ban on all 'External symbols of ideological, political, syndical, sportive,... belief" for city staff working in direct contact with the public (City of Antwerp, 2007a). The dress code was experienced however by the Muslim community of Antwerp as a restriction of the basic individual freedom of religion. A Women's activist group called $\mathrm{BOOH}$ ! (Boss Over Own Head) was established by a group of Muslimahs who defended the right to always wear a headscarf. At regular intervals they organized protest, catching the attention of local and national media alike.

In his book The Best Is Yet to Come, it was mayor Patrick Janssens (2006, p. 134) himself who had advocated a ban on all ideological signs for city staff: "despite my understanding, it is not appropriate to authorize the headscarf (or any other religious or political symbol) while exercising a public function, which has to visually express the neutrality of the government." The headscarf ban was just one of the measures in a broader attempt to guarantee the secular nature of the state. Another measure for instance consisted in not authorizing religious people to perform prayers at work.

Many of the politicians from Moroccan or Turkish decent in the socialist party and in the coalition parties resented the measure as a stigmatization of religious minorities. Janssens' original rationale to guarantee the political neutrality of the city was therefore subsequently complemented with the pragmatic policy goal to help support an ethnically mixed recruitment policy. Since the 1990s the municipality had tried to make the city staff more ethnically heterogeneous, but with little result so far. With the dress code, it was said that the resistance among the broader population to a mixed city staff would gradually diminish. Nevertheless, this resulted in a governmental paradox; while the aim was to make the city staff into a reflection of the ethnic diversity in the urban society, religious diversity as such should not be visible in front-office functions.

In our view, this first policy measure can be identified as a disciplinary power technique. The exercise of disciplinary power is quite common in professional settings, as it certifies that employees fulfil the general aims of a company. Still, a more symbolic issue was at stake in the context of city staff: the secular, neutral representation of the state and the political community as such was the main driver for the policy measure. The dress code then became the norm against which each individual civil servant's appearance needed to be evaluated. As we will now explain, this inevitably implied the construction of a new exclusionary fault-line of citizenship.

The municipal government considered it legitimate to make the basic freedom of religion conditional in order to guarantee the secular nature of the state. As Council Member Cathy Berx argued: "We have to learn to cope with diversity, but also with the predicaments of our democratic system of law. These state that fundamental rights and freedoms, like the right to free speech and the freedom of religion, are not absolute basic rights, and negotiations need to be made, in particular in the case of the neutrality of the public service." (City of Antwerp, 2007b, p. 1721) So it was in the defence of a specific secular interpretation of universal citizenship that certain basic laws were denied to a subset of citizens.

The municipality stigmatized any refusal to comply with the dress-code as a sign of immature citizenship and religious fanaticism. As mayor Janssens (2006) put it: "In such a situation, the employee needs to be mature enough to choose for the neutrality of his function instead of being loyal to an absolute belief." (2006, p. 134) Put differently, the norm of the dress code established a political fault-line between those who could deal with religion in a mature way and those who could not.

The municipal government denied that it wanted to extend this norm outside the confines of its institutional boundaries. For mayor Janssens, "the headscarf and other religious symbols are not forbidden in Antwerp (...). We only ask for people to take off their symbols during their public job." (City of Antwerp, 2007c, p. 64) Again this is common for disciplinary power: the disciplinary norm is organically bound up with the institutional context in which it originated and cannot travel freely outside its original context. However, when a government promotes a disciplinary measure, governmental norms tend to inspire other institutional contexts and contaminate them. It is the legitimacy of the state which strengthens institutional 'mirroring'.

In fact, this is what happened in the case of the headscarf ban; suddenly it started to trickle down in other public services as well. For example, in public day-care centres employees were forbidden to wear a headscarf. But also in public schools the fault-line was drawn, forcing young Muslim women to stop wearing headscarves at school. What started out as an institutional norm thus grew into a broader imagination of the public tolerance for religious diversity. In the original context of the city administration women with a headscarf were offered back-office jobs, but the symbolical effect was unprecedented. The establishment of the widely supported $\mathrm{BOOH}$ ! was one of the clear indications that religious migrant minorities felt stigmatized and relegated to a second-class, merely formal citizenship in the urban political community. 


\subsection{Bio-Politics and the Normalization of Urban Neighbourhoods}

During Janssens' term as mayor of Antwerp, the municipal administration transformed into an apparatus that aimed to increasingly influence the composition of its urban population. The objective was twofold: more better-off people had to live in the city and the number of poor people had to decrease. In this paragraph we discuss the means and the strategies by which this twosided concern was set into motion. In our view, both strategies illustrate the functioning of a bio-political technique that aims to regulate and effectively normalize who lives where. We discuss how the attraction of better-off people became part and parcel of Antwerp's loudly approved urban renewal policy, whereas reducing the number of poor inhabitants in the inner city remained a silent process. The latter took the form of backstage agreements between administrators and local politicians. From 2008 on, this silent Antwerp experiment became more or less official legislation in the Flanders Region: from then on a system of technically refined parameters 'proved' that a certain percentage of poor inhabitants was the sufficient justification for a deliberate freeze in the social housing supply. A vast majority of these urban poor were immigrants, people to whom both ownership and the better equipped rented houses remained unattainable (Vaneste, 2007).

Let us now return to the more publicly visible aspect of these policy measures, the attempt to attract specific high-profile groups to the city, such as dual earners, higher income groups, and young families. The Municipal Coalition Plan repeatedly identified them as target groups whose presence would help create a better functioning and bustling city: "The municipality wants to get more young people into the city. Firstly young families with children and baby boomers coming from the suburbs. Therefore high-standard urban living is one of the major tasks for this policy term and the years to come." (City of Antwerp, 2007d, p. 3) This endeavour was attached to the Municipal Spatial Structure Plan, a document indicating the strategic interventions to be made. Under Janssens' administration, this Plan was used more systematically to integrate new housing in urban renewal projects. This endeavour was rather new for Flanders as most of its real estate projects are developed almost without prior urban design or planning. The Antwerp Coalition Plan completed its focal objective with a bulk of interventions in the domain of arts and culture, education, shopping and nightlife inter alia, in order to become the 'bustling city' where youngsters, young adults and young families like to live (City of Antwerp, 2007d, pp. 3, 17, 27).

Taking its own apparatus and governance techniques into account, the Coalition Plan noted that 'good and goal-oriented governance' was the best way to rejuvenate Antwerp's 'leadership and its leading character. By showing that bigger towns like ours have to offer a lot of fascinating things, to young families with children as well' (City of Antwerp, 2007d). The Janssens' administration took a leading role in the deregulation of older business models by reshuffling municipal departments into corporate units and granting specific administrations extensive autonomy, such as the planning department. This has been instrumental in attracting substantial funds for big strategic renewal projects. The former retirement fund of Antwerp was converted into the real estate and urban development company Vespa. Vespa became capable of intervening in local housing markets and in this way acted upon important parameters that influence the composition of the urban population. Vespa was said to influence the supply and demand of existing and new housing, inter alia by intentionally buying and selling land properties and buildings on specific locations (e.g. disadvantaged neighbourhoods, ragged areas and/or newly designed districts).

The second part of the case we discuss here, deals with the overall reduction of social housing opportunities in Antwerp, especially in the city centre's social rental sector. Between 2004 and 2012 the number of socially rented dwellings decreased by nine percent in the city, some districts showed an even bigger decline. This reduction was achieved by demolishing older dwellings, assembling formerly individual apartments, freezing programs for new social houses, and selling social parcels to commercial companies. In some remote neighbourhoods however, new social housing projects were started nevertheless (e.g. in the harbour district far north). From 2005 on, the social housing companies did not initiate any major project in the city centre, and when some smaller corporations did apply for such projects, they received a municipally disapprobation.

Although Antwerp did not deploy income policies for new residents (as Rotterdam for instance did), the city did try to interfere in its demographic composition, especially by reducing its lowest socioeconomic segments, many coming from an immigrant background. The administrative parameters to do so were prepared and composed from 2003 onwards, and since 2008 the Antwerp dispersion policy for rental housing in the public sector became largely standard policy in Flanders. From then on, the municipality had more legal and technical instruments to freeze or decrease the number of social housing in specific neighbourhoods where the rate of social (rental) housing was considered to be too high.

The legal framework provided refined techniques to calculate the precise number of rented social housing in each statistical sector. These parameters created the illusion that the considerations to be made were purely technical instead of societal or political. This opinion seems to be illustrated by casting an eye on the statements and discussions in the Flemish Parliament on this selective and area-bound public housing policy. 
The preparation and establishment of this legislation was discussed in terms of risks for the real estate sector and the deliberate reduction of socially rented housing stock in the inner cities itself was not discussed as a matter of public interest.

Today experts in the social housing sector are critical on this issue. Gert Eyckmans, managing director of a smaller housing corporation in the Antwerp region, notifies that especially in the districts and neighbourhoods with high rates of social housing, the public sector should remain present and sometimes even increase its activities. "The mere technical calculations veil what in the near future will be needed in these neighbourhoods. As urban demography will rise, these districts in fact will need even more dwellings in the public sector. A great deal depends on how one positions the referential values decisive to whether one increases or decreases the supply". In this context Janssens' policy was quite different compared to that of other cities where corporations and the city administration decided to remain present in these neighbourhoods.

Combined, the two dimensions of the policy installed a new topography of in- and exclusion. As affordability of private rental housing is growing weaker in Flanders, the public rental sector functions as a shelter for urban tenants, especially for people with low incomes (Winters \& Elsinga, 2008). This precarity is even fiercer for ethnic minorities for whom tenant properties in the private sector are often unaffordable because of repeatedly reported discrimination by landlords (for an overview, see Özüerken \& Van Kempen, 2003). Due to the silent and technocratic relocation of social housing however, poor people are 'in a natural way' displaced to the urban periphery where they symbolically live through their second-rate citizenship. Still they remain dependent on amenities in the inner city, and as social workers and grass-roots associations report, poor people perceive the new suburban environments often as inadequate, especially in terms of social networks. By contrast, the inner-city tends to become a purified domain, a place for leisure and consumption, a realm for middle- and upper-class residents. The neighbourhoods where the decrease in social housing was most dramatic were often those districts that functioned as an arrival city for immigrant newcomers, a particularly obvious example being the area around the central railway station, where a large renewal program was deployed. This reshuffling of urban functions, combining the restyling of urban areas with an implicit regulation of who lives where, can be conceived as a bio-political intervention on the definition of urban citizenship.

\subsection{Etho-Politics and the Regulation of Behaviour in Public Spaces}

As a third case, we discuss Antwerp's local security pol- icies, focussing on the Local Administrative Penalties (LAP's). In short, LAP is a system of administrative fines that remains outside the regular court-handling of sanctions. During Janssens' term, the LAP's became the corner stone of the so-called 'integrated security poli$c y^{\prime}$. We argue that these fines can be interpreted as a specific etho-political power instrument. The LAP system was initially designed to identify and re-educate youngsters and individuals behaving inappropriately in public spaces. As the system was designed to reintegrate these individuals, experts considered it to be generally inclusive (Devroe, 2010). In its implementation, however, the system thereby drew new lines of exclusion, as citizens relying on public spaces for daily activities had to face new and unknown regulations, and particular areas housing ethnic minorities were subjected to close attention and behavioural control, especially with respect to these minorities' youngsters.

At the end of 2004 the Antwerp municipality presented its 'Plan Safety', a master plan in the struggle against urban decay, petty crime and what was phrased as 'problems of quality of life', e.g. noise nuisances, dirt in public space or dog waste on the sidewalks. The approach was said to be 'integral' as civil servants started a systematic collaboration with social workers, police forces and juridical officials. Through new forms of 'assertive outreaching' the administration wanted to make house calls, focusing on hard-toreach groups and multi-problem families. An important strand of the approach was oriented towards young adults and early offenders, most of them belonging to ethnic minorities. Night-shops and non-profit gathering places for immigrants would be followed more stringently than before because they were suspected of being involved in drug trade and causing public nuisance. The bulk of measures was supplemented by actions bound to migrant concentration neighbourhoods and specific target groups (under aged immigrant offenders with no criminal record).

New forms of mediation and early intervention were developed. Municipal cleaning and restoration campaigns were set up, involving both city services and neighbourhood residents. The 'Plan Safety' did not yet entail administrative (financial) sanctions. Its reach was broader and encompassed a wide range of programs and counselling instruments aimed at supporting both victims and perpetrators of nuisance, while using these programmes for building up a local policy-relevant database. The programme was monitored citywide, enabling the mayor to request immediate interventions. Nevertheless, all these local programmes and interventions remained curative or preventive, as for most offenses there were no repressive municipal instruments.

On the national level however, the idea became dominant that municipalities should indeed be able to act repressively. Local authorities and particularly mayors should be able to punish small offences, such 
as noise nuisance and illegal dumping. By establishing a financial fine instead of a legal prosecution, a double logic could be installed: petty criminality would no longer remain unpunished, and prosecutors' caseload would be diminished, thus creating time for dealing with serious offences. The installation of the LAP's was said to be a form of de-penalisation, a rather veiling label as the offending citizens were still being punished while no longer protected by ordinary juridical rights and procedures.

However, in order to make these federal LAP legislations locally applicable, municipalities had to organize a complex of new regulations and implementations: new civil servant functions had to be created, a list of punishable offences had to be compiled, and these new regulations had to be integrated with existing local practices. Moreover, a mediating organism and procedure had to be installed, as the federal law on LAP's guaranteed that the suspected offender could appeal to a mediator.

What types of behaviour did the LAP legislation consider to be offences? The national legislator only indicated the general types of acts and situations that were apt for local fines, in the sense that classic penal procedures no longer applied. The majority of the legislative energy was mobilized for the technical depenalisation, rather than reflecting on the implications of the radical shift in criminal justice and its implementation. Major aspects of the latter now became the sole responsibility of mayors and their municipal councils. Moreover, the de-penalisation created a hyper localized legislation, with town-based regulations, sometimes comprising up to 200 pages listing offensive actions.

When the LAP's were implemented and the new apparatus became operational, something paradoxical happened, at least in Antwerp. The procedure proved to be a lot easier than the more refined interventions and campaigns from the initial 'Plan Safety'. Small offences were being fined massively, and in some parts of the town problems indeed seemed to diminish. Civil society discussed the logic used to determine what counted as an offence, and who was to be suspected of such offences. The officials declaring the offences were small in number, but since they were not uniformed, they were ubiquitous and invisible. These peculiar features, we argue, made the LAP into an etho-political power tool.

As in the first two cases, these fines tried to regulate citizens' behaviour. In the case of Antwerp, the LAP's had a wide-ranging impact on the power relations between citizens and their political communities. Because the decision determining what counts as an offence was now taken at a local level, local actors became increasingly able to influence those definitional practices. The range of 'acceptable behaviour in the public space' was transformed radically as municipal au- thorities now obtained the responsibility and the competence to partially define both its range and content.

The LAP's regulate citizens' behaviour in a way that differs qualitatively from the disciplinary and the biopolitical technique, in that the former intervenes on the individual without restricting itself to a limited institutional setting. This can be illustrated by the case of the shop owners in Antwerp's Main Street wanting to get rid of beggars and homeless people in what they consider to be 'their' street. In federal legislation begging is not forbidden and for some beggars, the activity may be a substantial strategy to obtain an income. However, the shop owners perceived begging to be a form of nuisance, and managed to persuade the local authorities not to tolerate such behaviour. Instead of police officers starting a juridical procedure again and again, LAP officials could fine the beggars much easier and seemingly more effectively, as the beggars did disappear from Antwerp's Main Street. In terms of ethopolitics, the beggars probably internalized the required dispositions as they not only evaded the Main Street but other popular shopping areas as well. Unlike disciplinary power techniques, the LAP's are not bound to any one particular place: the fines could be distributed everywhere. The risk of being fined is ubiquitous and in this sense 'virtual': the eyes of the regulating power seem to be patrolling permanently. Wherever the beggar goes, his mere presence and activity may suffice to be accused as committing an offence. As beggars may choose for even more anonymity, the LAP's can be considered to be effective not only in fighting nuisances but also in making some people more invisible. This may (re)produce a new articulation of inequality for the societal means to label what should be treated as nuisance, as some are granted a legitimate 'voice', whereas others are not. In combination with the ethopolitical techniques, the already existent inequalities may therefore reinforce themselves. Not all citizens can thus realize their right to the city and its amenities; this right seems to become more conditional, bound to specific behaviours that get labelled 'normal'.

\section{Conclusion and Discussion}

In this article we explored how some policy measures endorsed by Antwerp's municipal government between 2003 and 2012, can be interpreted as power techniques intended to regulate the behaviour, lifestyles and identities of its citizens. To round up this contribution we will go one step further by identifying what we think is the key thread running through these policy measures. In this section we will, in other words, sketch the general 'governmental rationality' emerging from particular uses of the power techniques described above. In doing so, we will situate the logic underlying Antwerp's governance within broader political philosophical discussions on citizenship. 
We argue that Antwerp's governance shared a number of key characteristics with the 'liberal' tradition in political philosophy. According to liberal philosophers such as John Rawls or Isaiah Berlin governments should only interfere with their members' behaviour if that behaviour forms a threat to the universal freedom of other members. Individuals are, to put it differently, free to live and develop their identities as they please, without fear of the state imposing its preference for any particular conception of a 'good' citizen. In this vein, Antwerp's municipality legitimized its policy measures pertaining to beggars, civil servants and social housing in the name of a universal good and the protection of the free individual. This general vision on urban citizenship was summarized symbolically by the new city slogan: 'The city belongs to everyone'.

In spite of this inclusive rhetoric, a number of tensions inherent to such liberal universalist accounts arose. These tensions can be clarified by invoking two recurring critiques of philosophical liberalism. Firstly, communitarian authors such as Alasdair Maclntyre and Michael Walzer have argued that all conceptions of citizenship, even liberal ones, are inevitably rooted in specific cultural-historical contexts. With respect to Antwerp, this became clear when we analysed the concrete techniques the municipality used to put its universalist, inclusive conception of citizenship into practice. The three policy measures analysed in this article all used power techniques enforcing and therefore assuming a particular 'normal' conduct for its citizens. As a result, a new topography of inclusion and exclusion emerged: 'normal' ways of behaving or displaying one's identity were distinguished from their 'deviant' counterparts.

Interestingly, these distinguishing and normalizing practices were generally legitimated by invoking a universalist, inclusive reasoning. The city officials' dress code forbidding the display of religious symbols was not legitimized by referring to a particular conception of a Flemish or autochthonous identity, but rather by referring to the secular, a-cultural nature of the state. In practice, however, this meant that only a small minority of the civil servants had to adjust their appearance to the new institutional context, thus establishing the majority of individuals not wearing religious symbols as the general norm. Similarly, the municipal government sought to obtain a more ideally 'mixed' urban population by attracting high-profile residents and by gently pushing out the poorer, often 'coloured', segments of its citizenry. And in a different vein, the LAP's formally prescribed detailed rules of conduct for public spaces, thereby establishing what was to be the right behaviour in particular public spaces. Out of many, the example was given of begging in a popular shopping street, which from then on was considered to be inappropriate for the economic function of that space.

Secondly, republican and democratic authors such as Hannah Arendt, Iris Marion Young and Chantal Mouffe have argued that a liberal, universalist conception of the political community neutralizes the conflicts between different groups and individuals, whereas in reality they compete with one another for a place in the public sphere. Whether the municipality was dealing with civil servants wearing headscarves, beggars in a shopping area, or people from lower socioeconomic classes searching for an affordable place to live: the three of them were invariably excluded from specific parts of the public sphere in name of a broader, universal good. The struggle between such groups to belong to that public sphere was taken out of the picture, to improve the general appeal of the city. The image created by the municipality was one of a public order without conflicts, a transparent public sphere without groups competing with one another. The LAPfines emerged out of the intention to guarantee a more 'liveable' public order: the sanctions in the shopping street were not considered to be the final result of a struggle between shop owners, consumers and beggars as equal members of the political community. The ban on visibly wearing religious and cultural symbols for front-office civil servants was considered to be a precondition of a neutral, tolerant government, rather than the result of a cultural struggle for recognition between a majority and its minorities. And, in a similar vein, the city's housing policy was no longer seen as a competition between rich and poor for the right to live in the city centre, but as a technical affair which can (and has to be) dealt with in a formal way, based on mathematical equations that pre-empt any public debate.

The implications of this double critique on the liberal, universalist conception of political citizenship became clear by examining the policy techniques that were used by the municipal government. The key thread running through these policy techniques, we argue, is that the city should be made as 'liveable' and attractive as possible for the highest common denominator: the city belongs to everyone. From our reading, however, it appears that this universality is (inevitably) highly conditional when put into practice: in every of the three policy techniques the municipality used a specific conception of what the 'normal' conduct of its individual members ought to be. The interests of the majority of people who made use of the city are thereby given priority vis-à-vis those of the deviant minorities. In others words, the city belongs just a little bit more to those who behave, live or express themselves appropriately.

In October 2012, Patrick Janssens lost the municipal elections to Bart De Wever and his New-Flemish Alliance. The newly elected majority identified itself with a markedly different rhetoric, prolifically replacing the old, universalist slogan by the more demanding 'Respect for A(ntwerp)'. Interestingly though, while the 
overt rhetoric seemed to undergo a profound transformation, the power techniques established by the previous majority remained in place. From an Urban Politics perspective, the continuity between the former and the current municipality's construction of citizenship may appear as something of a strange anomaly. From a Foucauldian perspective, however, we have been able to distinguish between the rhetoric displayed by those in power, and the actual techniques deployed to regulate citizenship in practice. Focussing on 'how' citizenship-and thereby, ethnicity-is regulated serves as an enriching complement to existing studies of urban politics. As it turns out, to become one of Antwerp's true citizens, substantially more is required than simply being granted the right legal status. As both mayors have taught their citizens, it is at least as important to behave and live up to the city's standards.

\section{Conflict of Interests}

The authors declare no conflict of interests.

\section{References}

Barry, A., Osborne, T., \& Rose, N. (1996). Foucault and Political Reason. Liberalism, Neo-Liberalism and Rationalities of Government. Chicago: The University of Chicago Press.

Barth, F. (1969). Ethnic Groups and Boundaries. The Social Organization of Cultural Difference. Oslo: Universitetsvorlaget.

City of Antwerp (2007a). Dienstnota D2007.046. Antwerp: City of Antwerp.

City of Antwerp (2007b). Gemeenteblad-n²39 Interpellatie Raadslid Piryns. Dresscode. Antwerp: City of Antwerp.

City of Antwerp (2007c). Gemeenteblad- $n^{\circ} 4$ Bestuursakkoord 2007-2012. Toelichting, bespreking en goedkeuring. Introductie beleidsrichtlijn. Antwerp: City of Antwerp.

City of Antwerp (2007d). Bestuursakkoord 2007-2012. Antwerp: City of Antwerp.

De Decker, P., Kesteloot, C., De Maesschalk, F., \& Vranken, J. (2005). Revitalizing the City in an AntiUrban Context: Extreme Right and the Rise of Urban Policies in Flanders, Belgium. International journal of Urban and Regional Research, 29(1), 152171.

De Verteuil, G. (2006). The Local State and Homeless Shelters: Beyond Revanchism? Cities, 23(2), 109-120.

Devroe, E. (2010). Overlast voor of door jongeren. In F. Gazar, C. De Craim \& E. Traets (Eds.), Délinquance juvénile, à la recherché des réponses adaptées (pp. 115-135). Apeldoorn: Maklu.

Fainstein, S. (2010). The Just City. New York: Cornell University.
Foucault, M. (1984). The Politics of Health in the Eighteenth Century. In P. Rabinow (Ed.), The Foucault Reader (pp. 273-289). New York: Pantheon Books.

Foucault, M. (1988). Madness and Civilization. A History of Insanity in the Age of Reason. New York: Vintage Books.

Foucault, M. (2001). The Political Technology of Individuals. In J. D. Faubion (Ed.), Essential Works of Foucault 1954-1984: Power (pp. 403-417). New York: New Press.

Foucault, M. (2004). Society Must Be Defended. London: Penguin Books.

Foucault, M. (2007). Security, Territory, Population. Lectures at the Collège de France 1977-1978. New York: Palgrave Macmillan.

Foucault, M. (2008). The Birth of Biopolitics. New York: Palgrave Macmillan.

Hindess, B. (2000). Citizenship in the International Management of Populations. American Behavioral Scientist, 43(9), 1486-1497.

Isin, E. F. (2002). Being Political: Genalogies of Citizenship. Minneapolis: University of Minnesota Press.

Isin, E., \& Turner, B. (2007). Investigating Citizenship: An Agenda for Citizenship Studies. Citizenship Studies, 11(1), 5-17.

Janssens, P. (2006). Het beste moet nog komen. Antwerpen: Book \& Media Publishing.

Malešević, S. (2004). The Sociology of Ethnicity. London: Sage Publications.

Marcuse, P. (2009). From Critical Urban Theory to the Right to the City. City: Analysis of Urban Trends, Culture, Theory, Policy, Action, 13(2-3), 185-197.

Marshall, T. H. (1963 [1998]). Citizenship and Social Class. In G. Shafir (Ed.), The Citizenship Debates. A Reader. Minneapolis: University of Minnesota Press.

Mitchell, D. (2005). The S.U.V Model of Citizenship: Floating Bubbles, Buffer Zones, and the Rise of the 'Purely Atomic' Individual. Political Geography, 24, 77-100.

Mitchell, D. (2009). Governmentality. Power and Rule in Modern Society. Thousand Oaks: Sage.

Olson, K. (2008). Constructing Citizens. The Journal of Politics, 70(1), 40-53.

Özüerken A. S., \& van Kempen, R. (2003), Dynamics and Diversity: Housing Careers and Segregation of Minority Ethnic Groups. Housing, Theory and Society, 20(4), 162-171.

Raco, M. (2003). Governmentality, Subject-Building, and the Discourses and Practices of Devolution in the UK. Transactions of the Institute of British Geographers, 28(1), 75-95.

Raco, M. (2009). From Expectations to Aspirations: State Modernisation, Urban policy, and the Existential Polititics of Welfare in the UK. Political Geography, 28, 436-444.

Rose, N. (2000). Community, Citizenship, and the Third 
Way. American Behavioral Scientist, 43(9), 13951411.

Schinkel, W. (2010). The Virtualization of Citizenship. Critical Sociology, 36(2), 265-283.

Smith, N. (1998). Giuliani Time: The Revanchist 1990s. Social Text, 57, 1-20.

Smith, M. P., \& McQuarrie, M. (Eds.) (2012). Remaking Urban Citizenship. Organizations, Institutions and the Right to the City. New Brunswick/London: Transaction Publishers.

Swyngedouw, M. (2000). Belgium: Explaining the Relationship Between Vlaams Blok and the City of Antwerp. In P. Hainsworth (Ed.), The Politics of Extreme
Right. From the Margins to the Mainstream (pp. 120-143). New York: Pinter.

Uitermark, J., Rossi, U., \& Van Houtum, H. (2005). Reinventing Multiculturalism: Urban Citizenship and the Negotiation of Ethnic Diversity in Amsterdam. International journal of Urban and Regional Research, 29(3), 622-640.

Vaneste, D. (2007). Wonen en woonomgeving in België [Dwelling and dwelling environment in Belgium]. Gent: Gent Academia Press.

Winters, S., \& Elsinga, M. (2008). The Future of Flemish Housing. Journal of Housing and the Built Environment, 23(3), 215-230.

\section{About the Authors}
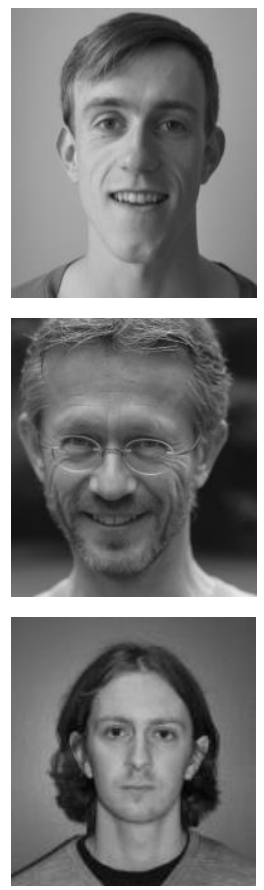

Nicolas Van Puymbroeck

Nicolas Van Puymbroeck studied Philosophy and Urban Sociology. Supported by the Flemish Fund for Scientific Research, he is preparing a doctoral dissertation on the contested politics of urban citizenship in contemporary multicultural cities. Recently he published a book entitled 'Migration and the Metropolis, 1964-2013' on the history of urban integration policies and the migrant civil society in Antwerp. His main interests are urban policies, processes of (de-)politicization and identity politics.

\section{Paul Bondel}

Paul Blondeel studied adult education and worked for twenty five years as an urban ethnographer in the Netherlands (Rotterdam region) and in Belgium (Brussels, Ghent and Antwerp). His domain of research is the discovery and implementation of area-specific qualities in social and spatial planning. He is writing a PhD at the university of Antwerp (design sciences). Within the Spindus research framework he developed new methodologies to enhance spatial quality in small towns.

\section{Robin Vandevoordt}

Robin Vandevoordt studied sociology and literature at the Universities of Antwerp (Belgium) and East Anglia (U.K.). Supported by the Flemish Fund for Scientific Research, he is currently writing a PhD on moral cosmopolitanism, focusing more particularly on rivalling discourses on refugees. His general research interests are in the sociology of culture and morals, and social theory. 